\title{
THIẾU HỤT VITAMIN D VÀ KHÁNG INSULIN TRONG HỘI CHÚNG CHUYỄN HÓA
}

Nguyễn Trọng Nghĩa, Nghiên cúu sinh Truờng Đại học Y Dượ, Đại học Huế, chuyên ngành Nội khoa

\section{SUMMARY \\ Vitamin $D$ deficiency and insulin resistance in metabolic syndrome}

Vitamin D is one of the essential nutrients to sustain the human health. As a member of the steroid hormone family, it has a classic role in regulating metabolism of calcium and a non-classic role in affecting cell proliferation and differentiation. With the finding of the vitamin D receptor in nearly every tissue and the more recent discovery of thousands of vitamin D receptor binding sites throughout the genome controlling hundreds of genes, the interest in vitamin D and its impact on multiple biologic. Therefore, vitamin $D$ has many effects include xenobiotic detoxification, oxidative stress reduction, neuroprotective functions, antimicrobial defense, immunoregulation, anti-inflammatory, anticancer actions, and cardiovascular benefits.The metabolic syndrome is a constellation of cardiometabolic risk factors that tend to cluster together in affected individuals more often than predicted by chance.The presence of the metabolic syndrome substantially increases the risk of developing type 2 diabetes and cardiovascular disease, and is associated with a range of adverse clinical outcomes, many of which are closely associated with aging.Excess energy stores in the adipose tissue and other organs as lipids, promoting lipotoxicity and metabolic inflammation, activating intracellular protein kinases to impair insulin signaling components, and resulting in insulin resistance. Insulin resistance is the key etiologic defect that defines metabolic syndrome, a group of interrelated disorders, including obesity, hyperglycemia, dyslipidemia, and hypertension. This review focuses on the association between hypovitaminosis $\mathrm{D}$ and the development of metabolic syndrome through its effects on insulin resistance in metabolic syndrome.

\section{TÓM TẮT}

Vitamin $\mathrm{D}$ là một trong các dưỡng chất thiết yếu để duy trì sức khỏe con người, là một thành viên của gia đình hormon, nó có một vai trò kinh điển trong điều hòa chuyển hóa calci và thêm vai trò mới trong ảnh hưởng đến tăng sinh và biệt hóa tế bào. Với việc tìm thấy các thụ thể vitamin $\mathrm{D}$ trong hầu hết tất cả các mô và phát hiện gần đây của hàng nghìn thụ thể vitamin $\mathrm{D}$ gắn với bộ gen kiểm soát hàng trăm gen. Sự quan tâm đến vitamin $\mathrm{D}$ và tác động của nó đối với nhiều quá trình sinh học đã được chứng minh bằng hàng nghìn ấn phẩm mồi năm trong nhiều năm qua. Tác dụng của vitamin $\mathrm{D}$ bao gồm giải độc hóa chất, giảm stress oxy hóa, chức năng bảo vệ thần kinh, tính kháng khuẩn, điều hòa miễn dịch, tác dụng chống viêm, chống ung thư và lợi ích tim mạch.Hội chứng chuyển hóa là một tập hợp của các yếu tố nguy cơ chuyển hóa tim, có khuynh hướng nhóm lại với nhau ở các đối tượng bị ảnh hưởng hơn là dự đoán một cách tình cờ. Sự hiện diện của hội chứng chuyển hóa làm tăng đáng kể nguy cơ xuất hiện đái tháo đường típ 2 và bệnh tim mạch, từ đó liên quan chặt chẽ đến quá trình lão hóa và một loạt các kết cục xấu.Năng lượng được dự trữ quá mức trong mô mõ và các cơ quan khác dưới dạng lipid, dễ gây ngộ độc lipid và tình trạng viêm do chuyển hóa, từ đó hoạt hóa các protein kinase trong tế bào và gây tổn thương các thành phần tín hiệu của insulin, và hậu quả là gây đề 
kháng insulin. Sự đề kháng insulin là nguyên nhân chủ yếu gây hội chứng chuyển hóa, một nhóm các rối loạn có mối tương quan với nhau, bao gồm béo phì, tăng glucose máu, rối loạn lipid máu và tăng huyết áp. Tổng quan này tập trung vào mối liên quan giữa giảm vitamin $\mathrm{D}$ và sự phát triển của hội chứng chuyển hóa thông qua ảnh hưởng của nó đối với kháng insulin trong hội chứng chuyển hóa.

Chịu trách nhiệm chính: Nguyễn Trọng Nghĩa

Ngày nhận bài: 12/11/2019

Ngày duyệt bài: 31/12/2019

\section{1. ĐẠI CƯƠNG VỀ VITAMIN D 1.1. Sự điều hòa tổng hợp và chuyển hóa vitamin D}

Vitamin $\mathrm{D}$ là chất mô tả chung cho tất cả các steroid mang hoạt tính sinh học của cholecalciferol, gồm 2 loại: Vitamin D2 là dẫn xuất của ergocalciferol, có hoạt tính với cấu trúc 9-carbon, chuỗi bên không bão hòa đơn, được sản xuất tổng hợp bởi sự quang phân của các sterol thực vật. Vitamin $\mathrm{D} 3$ là dẫn xuất của cholecalciferol, có hoạt tính với cấu trúc 8carbon, chuỗi bên bão hòa, được sản xuất chuyển hóa thông qua quá trình quang phân tự nhiên của 7-dehydrocholesterol trên bề mặt của da tiếp xúc với tia cực tím như ánh nắng mặt trời [8].

Dưới tác dụng của tia cực tím (bước sóng290-315 nm), 7-dehydrocholesterol được chuyển đổi thành tiền vitamin $\mathrm{D}$ trong da, ngay lập tức được biến đổi thành vitamin D3 bởi quá trình quang phân. Cả vitamin $\mathrm{D} 2$ và vitamin $\mathrm{D} 3$ có nguồn gốc từ sự tổng hợp trong da và chế độ ăn uống được vận chuyền bởi protein liên kết vitamin D (VDBP:
Vitamin $\mathrm{D}$ binding protein) theo dòng máu hoặc được lưu trữ trong tế bào mỡ và sau đó giải phóng vào tuần hoàn. Bước tiếp theo của quá trình chuyển hóa vitamin $\mathrm{D}$ bao gồm hai phản ứng hydroxyl hóa enzym liên tiếp dẫn đến hoạt hóa vitamin $\mathrm{D}$. Bước đầu tiên của hoạt hóa vitamin $\mathrm{D}$ là sự hình thành $25-\mathrm{OH}-\mathrm{D}$ trong gan bởi vitamin D-25-hydroxylase, là một loại enzym cytochrom P450, (chủ yếu là CYP2R1). Kế tiếp, 1,25-(OH)2-D (calcitriol, chất chuyển hóa có hoạt tính sinh học của vitamin $\mathrm{D}$ ) hình thành do kết quả của quá trình hydroxyl hóa 25-OH-D được thực hiện bởi 25-OH-D-1 $\alpha$-hydroxylase (CYP27B1). Enzym này không chỉ hiện diện trong ống thận, mà còn ở nhiều tế bào bao gồm đại thực bào, tế bào mõ̃ và tế bào $\beta$ tuyển tụy. 1,25 $(\mathrm{OH}) 2-\mathrm{D}$ gây ra sự thoái hóa của chính nó thông qua sự kích thích của 25-OH-D-24hydroxylase (CYP24A1). CYP24A1 là một enzym chịu trách nhiệm cho sự thoái hóa của cả calcitriol và tiền chất $25-\mathrm{OH}-\mathrm{D}$ thành các chất chuyển hóa không có hoạt tính sinh học, tức là acid calcitroic bài tiết qua mật. Nồng độ thấp của vitamin $\mathrm{D}$ và calci kích thích tuyến cận giáp giải phóng hormon tuyến cận giáp (PTH: Parathyroid hormone) và cảm ứng sự tổng hợp CYP27B1, dẫn đến tăng hoạt hóa calcitriol. 1,25- $(\mathrm{OH}) 2-\mathrm{D}$ có thể giảm tổng hợp của chính nó thông qua vòng phản hồi nghịch và giảm cả tổng hợp và tiết $\mathrm{PTH}$. Hormon tuyển cận giáp cũng có khả năng ức chế CYP24A1và cảm ứng tổng hợp yếu tố tăng trưởng nguyên bào sợi 23 (FGF:Fibroblast growth factor). FGF-23 điều hòa cân bằng nội môi vitamin $\mathrm{D}$ thông qua ức chế biểu hiện CYP27B1 ở thận và kích thích biểu hiện CYP24A1 dẫn đến giảm nồng độ calcitriol trong huyết thanh [26]. 


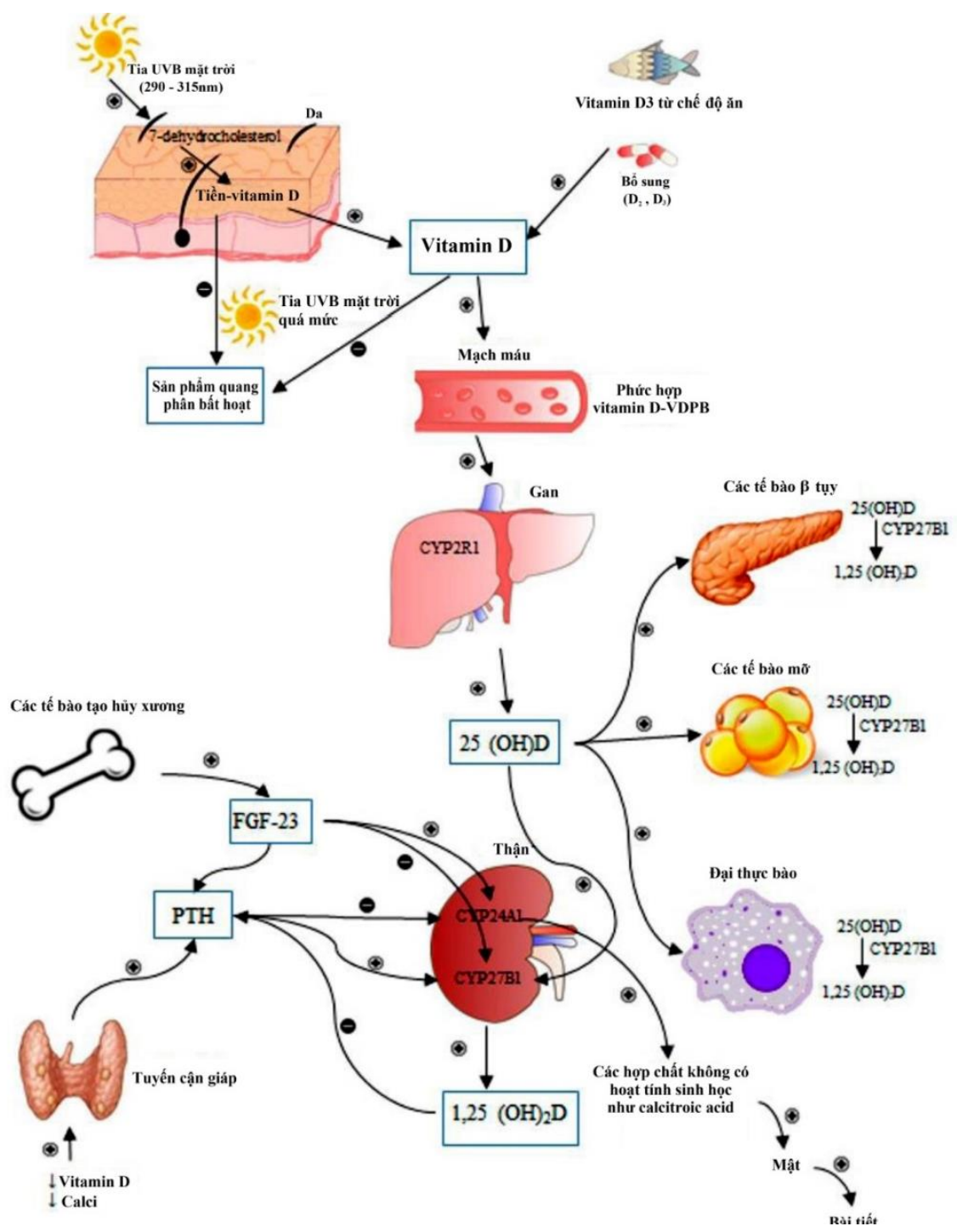

Hình 1. Sụ điều hòa tổng hợp và chuyển hóa vitamin D [26].

\subsection{Cơ chế hoạt động của vitamin $D$}

Vitamin $\mathrm{D}$ có tác dụng phiên mã gen thông qua các cơ chế hoạt động qua gen và không qua gen [14]

* Cơ chế hoạt động qua gen. Được trung gian thông qua thụ thể vitamin D (VDR: Vitamin D receptor), thuộc họ thụ thể hạt nhân và hoạt động như một yếu tố phiên mã được hoạt hóa bởi phối tử (ligand). Dạng hoạt động của vitamin D, 1,25-(OH)2-D, liên kết với VDR, từ đó tạo thành phức hợp 2 chuỗi không đồng nhất (heterodimer) với thụ thể retinoid X (RXR: Retinoid $X$ receptor). Sau đó, phức hợp 1,25(OH)2D3-VDR-RXR được chuyển vào nhân, nơi nó liên kết với các yếu tố đáp ứng vitamin D (VDRE: Vitamin Dresponsive elements) trong vùng khởi động của các gen đáp ứng vitamin $\mathrm{D}$. Sự tương tác giữa 1,25-(OH)2-D3-VDR-RXR và VDRE dẫn đến việc tuyển dụng các tổ hợp lõi enzym đa dạng chịu trách nhiệm cho việc tái cấu trúc chromatin, tạo điều kiện cho việc sửa đổi biểu sinh của các histone cũng như tuyển dụng RNA polymerase II.

Các thay đổi này điều hòa thuận hoặc nghịch sự biểu hiện của gen mục tiêu, bao gồm cả những việc chịu trách nhiệm cho sự tăng sinh và biệt hóa của các tế bào, hoạt 
động điều hòa miễn dịch và tân sinh mạch.

* Cơ chế hoạt động không qua gen. Được biểu hiện bằng sự kích hoạt của các phân tử tín hiệu (ví dụ, phosphatidylinositol-3 kinase, phospholipase $\mathrm{C}$ (PLC), $\mathrm{Ca}^{2+}$-calmodulin kinase II (CaMPKII), protein kinase A (PKA), mitogen-activated protein kinases (MAPKs), src, protein kinase $\mathrm{C}$ (PKC). Mục tiêu của các kinase này là các yếu tố phiên mã (ví dụ: SP1, $\mathrm{SP} 3$ và $\mathrm{RXR}$ ) lần lượt tương tác với VDRE trên vùng khởi xướng các gen đáp ứng vitamin $\mathrm{D}$. Vitamin $D$ cũng tham gia vào việc sản xuất tín hiệu truyền tin thứ hai (ví dụ, $\mathrm{AMP}$ vòng, $\mathrm{Ca}^{2+}$, các acid béo và 3 -phosphoinositide). Phạm vi của các phân tử tín hiệu được hoạt hóa có liên quan với loại tế bào và trạng thái trưởng thành của nó.

\subsection{Tình trạng vitamin $D$}

Chỉ số về tình trạng vitamin $\mathrm{D}$ là nồng độ chất chuyển hóa lưu hành của nó, cụ thể là 25$\mathrm{OH}-\mathrm{D}$, có thời gian bán hủy là 10 đến 19 ngày. Nồng độ 25-OH-D phản ánh mức độ vitamin $\mathrm{D}$ từ sự tổng hợp trong da và chế độ ăn uống.

Một số hiệp hội trên thế gới đã phát triển các hướng dẫn về tình trạng vitamin $\mathrm{D}$ nhằm xác định tình trạng thiếu hụt, thiếu và đủ vitamin D.

Bảng 1. Định nghĩa thiếu hụt vitamin D dụa trên điểm cắt 25-OH-D[6], [9], [15], [25].
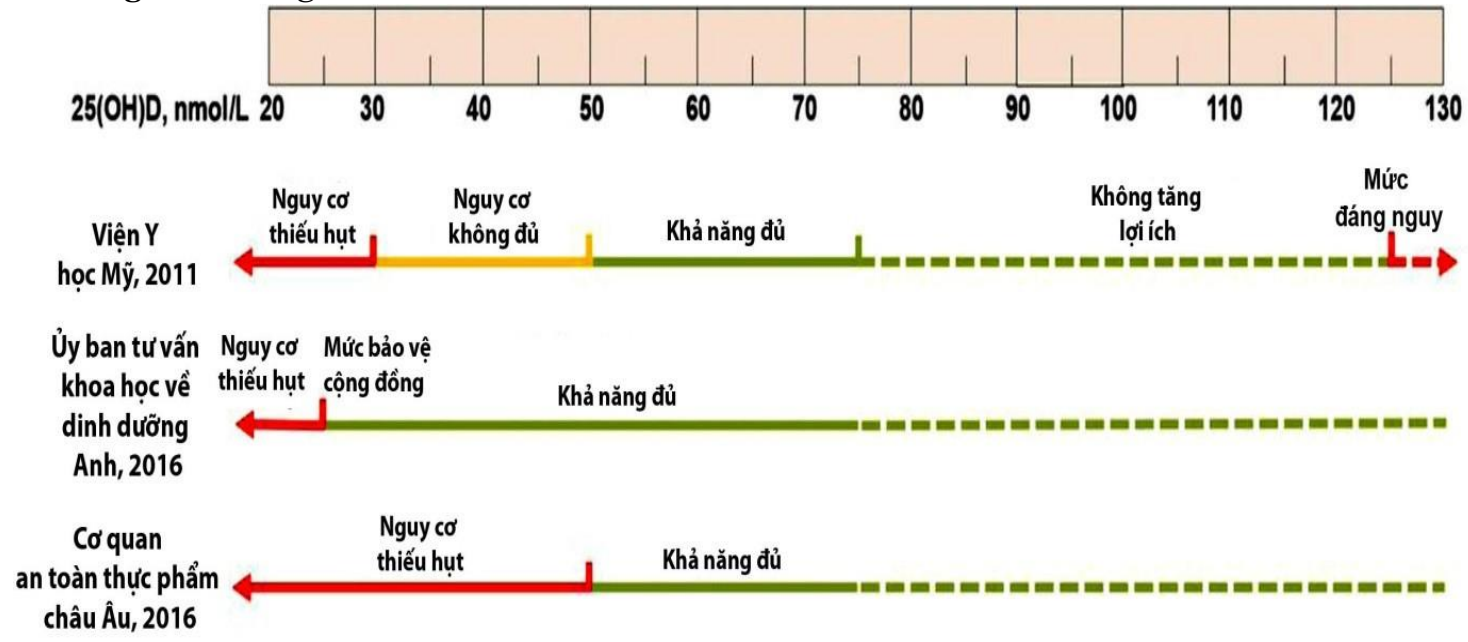

Hội Nội tiết

Mỹ, 2011

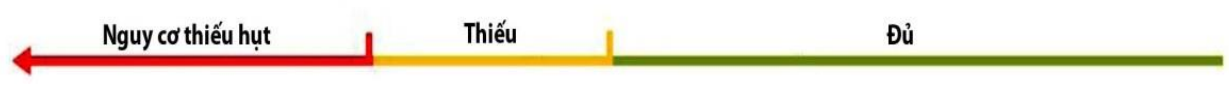

Ghi chú: đường đứt nét được hiển thị cho phạm vi 25-OH-D trong đó nhóm đồng thuận không đưa ra tuyên bố trực tiếp về tình trạng thiếu vitamin $\mathrm{D}$, đầy đủ hoặc nguy cơ gây hại.

\section{D}

\subsection{Nguyên nhân của thiếu hụt vitamin}

Nguyên nhân nguyên phát liên quan đến việc cung cấp vitamin $\mathrm{D}$ không đủ như: tiếp xúc không đủ với ánh sáng mặt trời, tiêu thụ không đủ thực phẩm có chứa vitamin $\mathrm{D}$ (các loài cá béo, sản phẩm từ sữa, nấm được chiếu xạ và thực phẩm tăng cường).

Nguyên nhân thứ phát liên quan đến suy yếu hấp thu, chuyển hóa hoặc gắn nhân tế bào của vitamin Dnhư: các bệnh về đường tiêu hóa (bệnh ruột non, cắt dạ dày, viêm tụy): liên quan đến kém hấp thu vitamin, bệnh gan (xơ gan mật, viêm gan): làm giảm hoạt động của 25-hydroxylase, bệnh thận: làm giảm hoạt động của 1-hydroxylase (viêm thận, suy thận) hoặc gây mất $25-\mathrm{OH}-\mathrm{D}$ vào nước tiểu (hội chứng thận hư), tiếp xúc với thuốc (phenobarbital, diphenylhydantoin): điều này gây ra sự dị hóa của cả $25-\mathrm{OH}-\mathrm{D}$ và $1,25-$ $(\mathrm{OH}) 2-\mathrm{D}$, suy tuyến cận giáp: làm suy yếu khả năng đáp ứng với calci máu cao bằng cách tăng hoạt động của 1-hydroxylase, đột biến cyp27b1: dẫn đến mất hoạt tính 1hydroxylase đối với 25-OH-D trong bệnh còi xương típ 1 phụ thuộc vitamin $\mathrm{D}$, đột biến 
VDR: làm giảm sự phiên mã của gen điều hòa vitamin $\mathrm{D}$ trong bệnh còi xương típ 2 phụ thuộc vitamin $\mathrm{D}$, kháng PTH: dẫn đến bệnh giả suy giáp, tức là giảm calci máu mà không được bù bằng cách tăng lưu giữ $\mathrm{Ca}$ tại thận hoặc huy động từ xương, mặc dù tiết $\mathrm{PTH}$ bình thường, kháng vitamin $\mathrm{D}$ : khiếm khuyết ở cả hấp thu tại ruột và tái hấp thu tại ống thận của phosphat, quá mẫn cảm với $\mathrm{PTH}$, và giảm quá trình 1-hydroxyl hóa 25-OH-D[8].

\section{VAI TRÒ CỦA VITAMIN D VÀ KHÁNG INSULIN TRONG HộI CHÚNG CHUYỂN HÓA}

\section{hóa}

2.1. Nguyên nhân của hội chứng chuyển

Nguyên nhân cơ bản của hội chứng chuyển hóa là thừa cân, béo phì, thiếu hoạt động thể lực và khuynh hướng di truyền. Mấu chốt của hội chứng là sự tích tụ của mô mỡ dẫn đến tình trạng kháng insulin. Các cytokin tiền viêm như yếu tố hoại tử $\mathrm{u}$, leptin, adiponectin, chất ức chế hoạt hóa plasminogen và resistin, được giải phóng từ mô mõ̃ phì đại, làm thay đổi và tác động xấu đến hoạt động của insulin. Kháng insulin có thể mắc phải hoặc do yếu tố di truyền. Suy giảm đường dẫn tín hiệu, khiếm khuyết thụ thể insulin và tiết insulin bị khiếm khuyết đều có thể góp phần vào kháng insulin. Theo thời gian, đỉnh điểm của nguyên nhân này gây ra sự phát triển của hội chứng chuyển hóa [3].

2.2. Cơ chế tác động của vitamin $D$ lên kháng insulin trong hội chứng chuyển hóa

2.2.1. Vitamin D duy trì chức năng tế bào $\beta$ tuy

Kết quả của các nghiên cứu tiền lâm sàng đã chỉ ra rằng vitamin $\mathrm{D}$ là một yếu tố điều hòa tiềm năng đối với tiết insulin, nồng độ $\mathrm{Ca}^{2+}$ và sự sống của các tế bào $\beta$ tụy. Một số nghiên cứu đã chứng minh rằng thiếu hụt vitamin $\mathrm{D}$ góp phần làm suy giảm tiết insulin qua trung gian glucose trong các tế bào $\beta$ tụy. Các nghiên cứu cho thấy sự tiết insulin qua trung gian glucose được phục hồi thông qua việc bồ sung vitamin D. Kết quả của một số nghiên cứu lâm sàng cũng đã chỉ ra rằng bổ sung vitamin $\mathrm{D}$ có liên quan đến việc cải thiện tiết insulin [26].

Thụ thể vitamin $\mathrm{D}$ và CYP27B1 được biểu hiện trong các tế bào $\beta$ tụy. Do đó, hoạt động của vitamin $\mathrm{D}$ trong các tế bào $\beta$ tụy được tác động trực tiếp thông qua sự liên kết của vitamin $\mathrm{D}$ với VDR. Chuột thiếu VDR có chức năng biểu hiện suy giảm tiết insulin sau khi nạp glucose và liên quan đến việc giảm tổng hợp insulin bởi các tế bào $\beta$ tụy dẫn đến giảm lượng insulin được lưu trữ. Calcitriol có thể kích thích trực tiếp tiết insulin vì VDRE được xác định trong vùng khởi động gen insulin trong tế bào $\beta$ tụy. VDRE không chỉ tạo ra sự phiên mã của gen insulin mà còn nhiều gen khác liên quan đến tổ chức tế bào, liên kết nội bào và sự tăng trưởng của tế bào $\beta[30]$.

Calci là một thành tố thiết yếu để trải qua thích hợp với nhiều quá trình nội bào qua trung gian insulin trong các mô đích, tức là mô cơ và mô mỡ. Nồng độ $\mathrm{Ca}^{2+}$ nội bào tối ưu không thể thiếu cho hoạt động insulin thích hợp. Sự truyền tải tín hiệu insulin bị suy giảm, liên quan đến giảm hoạt động của chất vận chuyển glucose do sự thay đồi của $\mathrm{Ca}^{2+}$ nội bào trong các mô đích, có thể dẫn đến kháng insulin ngoại biên. 1,25-(OH)2-D có ảnh hưởng đến sự nhạy cảm insulin thông qua việc điều hòa nồng độ $\mathrm{Ca}^{2+}$ ngoại bào và dòng chảy của nó qua màng tế bào, ngoài ra, thiếu hụt vitamin $\mathrm{D}$ góp phần làm tăng nồng độ $\mathrm{Ca}^{2+}$, từ đó có thể làm giảm hoạt động GLUT4 dẫn đến kháng insulin [26].

Vitamin $\mathrm{D}$ tham gia điều hòa dòng $\mathrm{Ca}^{2+}$ trong tế bào $\beta$ tụy. 1,25-(OH)2-D làm giảm biểu hiện của các kênh $\mathrm{Ca}^{2+}$ típ $\mathrm{L}$ dẫn đến thay đổi tín hiệu $\mathrm{Ca}^{2+}$. Cơ chế hoạt động nhanh không qua gen của vitamin D đã được chứng minh có liên quan đến việc tăng nồng độ $\mathrm{Ca}^{2+}$ trong tế bào chất kích thích cơ chế xuất bào của tiết insulin trong các tế bào tế bào $\beta$ tụy. Hiệu ứng này thông qua trung gian hoạt hóa hai con đường tín hiệu. Đầu tiên là quá trình hoạt hóa PKA để phosphoryl hóa các protein khác nhau tham gia với vai trò của các kênh $\mathrm{Ca}^{2+}$ phụ thuộc điện thế típ L liên quan đến gia tăng tiết insulin. Các đường tín hiệu thứ hai này bao gồm hoạt hóa tổng hợp 
inositol trisphosphate (IP3) và phospholipase $\mathrm{C}$ (PLC), góp phần giải phóng $\mathrm{Ca}^{2+}$ từ lưới nội chất và diacyloglycerol (DAG) để lần lượt kích hoạt PKC. Các PKC được kích hoạt có trách nhiệm phosphoryl hóa các kênh $\mathrm{K}_{\mathrm{ATP}}$ và $\mathrm{Ca}^{2+}$ phụ thuộc điện thế típ L. Tất cả các quá trình này dẫn đến khử cực màng tế bào chất và mở các kênh $\mathrm{Ca}^{2+}$ típ $\mathrm{L}$ và típ $\mathrm{T}$, nâng cao $\mathrm{Ca}^{2+}$ nội bào, sau đó kích thích tiết insulin. $\mathrm{PKC}$ cũng có thể huy động các vi túi bào (exosome) tiết ra cùng với nồng độ $\mathrm{Ca}^{2+}$ tăng cao thúc đẩy tiết insulin. Gia tăng nồng độ $\mathrm{Ca}^{2+}$ gây tiết insulin thông qua hoạt hóaCaMKII (Ca2+/calmodulin (CaM)dependent protein kinase II). CaMKII là một protein kinase threonine serine được định vị trong các vi túi bào tiết insulin. Chức năng chính của nó là thúc đẩy quá trình phosphoryl hóa các protein liên quan đến cả việc huy động và xuất bào của các vi túi bào insulin. Việc gia tăng nồng độ $\mathrm{Ca}^{2+}$ nội bào có thể gây ra biểu hiện của gen insulin thông qua protein liên kết với yếu tố đáp ứng AMP vòng (CREB: cAMP-responsive Element-binding Protein). CREB là một yếu tố phiên mã quan trọng liên quan đến việc duy trì phiên mã gen insulin hiệu quả, cảm nhận glucose, sự sống của tế bào $\beta$ tụy và sự xuất bào giải phóng insulin. Hơn nữa, calcitriol cũng điều hòa biểu hiện calbidin- $\mathrm{D}_{28 \mathrm{k}}$. Calbidin- $\mathrm{D}_{28 \mathrm{k}}$ là một protein liên kết $\mathrm{Ca}^{2+}$ ở tế bào chất liên quan đến việc kích thích tiết insulin thông qua sự điều hòa nồng độ $\mathrm{Ca}^{2+}$ nội bào. Vitamin $\mathrm{D}$ cũng làm tăng biểu hiện của parvalbumin, calbindin D-9k, chất trao đồi natri/calci (NCX: $\mathrm{Na}+\mathrm{Ca} 2+$ exchanger) và $\mathrm{Ca}^{2+}$-ATPase 1 b màng sinh chất và bơm $\mathrm{Ca}^{2+}$. Tất cả các protein này chịu trách nhiệm duy trì nồng độ $\mathrm{Ca}^{2+}$ thấp. vitamin $\mathrm{D}$ là một chất điều biến tiết insulin bởi sự khử cực được kích thích thông qua điều hòa $\mathrm{Ca}^{2+}$ nội bào[26].

2.2.2. Tác dụng của Vitamin D đối với tín hiệu và nhạy cảm insulin

Vitamin D không chỉ liên quan đến chức năng của các tế bào $\beta$ tụy, mà còn trong các mô đáp ứng với insulin, bao gồm mô mỡ, gan và cơ vân. Kết quả của một số nghiên cứu cho thấy vitamin $\mathrm{D}$ làm tăng nhạy cảm insulin trung gian thông qua liên kết của 1,25-(OH)2$\mathrm{D}$ với $\mathrm{VDR}$, cảm ứng biểu hiện các thụ thể vitamin $\mathrm{D}$ trên mô đích, cũng như hoạt hóa thụ thể được hoạt hóa bởi yếu tố biệt hóa ở peroxisome delta (PPAR- $\delta$ ). Vitamin D có khả năng kích thích các thụ thể vitamin $\mathrm{D}$ trong các mô đích đáp ứng với insulin. Trong các tế bào đáp ứng với insulin, 1,25-(OH)2-D tương tác với VDR, từ đó liên kết với RXR. Sau đó, phức hợp 1,25-(OH)2-D-VDRRXR liên kết với VDRE ở vùng khởi động gen thụ thể insulin người, gây hoạt hóa phiên mã gen thụ thể insulin được tăng cường và gia tăng số lượng thụ thể insulin. Biểu hiện cao của gen thụ thể insulin duy trì con đường tín hiệu insulin thích hợp. Do đó, chất chuyển hóa hoạt động của vitamin $\mathrm{D}$ dường như là chất kích thích biểu hiện thụ thể insulin, từ đó cải thiện sự nhạy cảm insulin. Thiếu hụt vitamin $\mathrm{D}$ có liên quan đến sự khởi đầu của tình trạng kháng insulin do giảm biểu hiện thụ thể insulin [4].

Sirtuin 1 (SIRT1) chi phối hoạt động deacetylase phụ thuộc NAD để kiểm soát sự phosphoryl hóa thụ thể insulin và cơ chất thụ thể insulin một cách độc lập với insulin. Người ta nhận thấy SIRT-1 điều hòa tích cực tín hiệu insulin thông qua kiểm soát quá trình phosphoryl hóa IRS-1, khử acetyl IRS-2, ức chế biểu hiện protein-tyrosine phosphatase $1 \mathrm{~B}$ (PTP-1B) và hoạt hóa $\mathrm{AKT}$ trong các tế bào nhạy cảm với insulin. Người ta cũng nhận thấy rằng việc bổ sung 1,25 $(\mathrm{OH}) 2-\mathrm{D}$ đã cải thiện quá trình chuyển hóa glucose thông qua việc tăng điều hòa dòng thác tín hiệu SIRT1/IRS1/GLUT4 và hấp thu glucose trong các ống cơ (myotube) $\mathrm{C} 2 \mathrm{C} 12$ [21].

Thụ thể được hoạt hóa bởi yếu tố biệt hóa ở peroxisome delta (PPAR- $\delta$ ) là một yếu tố phiên mã tham gia vào quá trình chuyển hóa và huy động các acid béo trong mô mỡ và cơ vân. 1,25-(OH)2-D có thể hoạt hóa PPAR- $\delta$ giúp cải thiện nhạy insulin. Sự hoạt hóa PPAR- $\delta$ qua trung gian 1,25-(OH)2-D làm giảm kháng insulin gây ra bởi các acid béo tự do ở cơ vân. Tác dụng của vitamin $\mathrm{D}$ trong việc giảm kháng insulin ở cơ vân cũng liên 
quan đến sự điều hòa nồng độ $\mathrm{Ca}^{2+}$ nội bào. Nồng độ $\mathrm{Ca}^{2+}$ tăng lên giúp tăng cường chuyển vị GLUT4 đến màng tế bào cơ và hấp thu glucose [26].

Thiếu hụt vitamin $\mathrm{D}$ cũng liên quan đến tăng nồng độ PTH liên kết với kháng insulin. PTH có thể làm tăng nồng độ $\mathrm{Ca}^{2+}$ tự do nội bào trong các mô đáp ứng với insulin, bao gồm cả cơ vân và mô mỡ. $\mathrm{PTH}$ làm giảm sự hấp thu glucose được kích thích thông qua insulin trong tế bào mỡ của chuột. PTH có thể gây ta đề kháng insulin thông qua việc giảm số lượng GLUT1 và GLUT4 trong màng tế bào, từ đó làm giảm sự hấp thu glucose. Do đó, PTH thúc đẩy kháng insulin thông qua việc giảm sự hấp thu glucose ở mô mỡ, gan và cơ [26].

Vitamin $\mathrm{D}$ ảnh hưởng đến tình trạng kháng insulin thông qua hệ thống reninangiotensin-aldosterone (RAAS). RAAS được biết đến với tác dụng ức chế hoạt động của insulin ở các mô ngoại biên và điều hòa nồng độ $\mathrm{Ca}^{2+}$ tế bào trong các tế bào cơ vân. Sự điều hòa này có thể thúc đẩy vận chuyển glucose qua màng do kích hoạt gia tăng số lượng GLUT4. Hơn nữa, angiotensin II thúc đẩy tạo ra ROS thông qua kích hoạt $\mathrm{NF}-\kappa \mathrm{B}$ bởi nicotinamide adenine dinucleotide phosphate (NADPH), từ đó lần lượt kích hoạt kháng insulin trong cơ vân. Sự biểu hiện của renin và sản xuất angiotensin II tăng lên ở chuột không có thụ thể vitamin $\mathrm{D}$ và sử dụng 1,25- $(\mathrm{OH}) 2-\mathrm{D}$ ức chế sinh tổng hợp renin. Do đó, vitamin $\mathrm{D}$ có thể cải thiện nhạy cảm insulin thông qua ức chế RAAS. Thiếu vitamin $\mathrm{D}$ cũng liên quan đến sự xâm nhập của chất béo trong cơ vân xuất hiện độc lập với khối lượng cơ thể và góp phần làm giảm tác dụng của insulin [26].

Vitamin $\mathrm{D}$ còn có tác dụng đối với quá trình tạo mỡ và tân tạo glucose ở gan. Hoạt động này có được trung gian thông qua các con đường khác nhau được điều hòa bởi vitamin $\mathrm{D}$ bao gồm protein kinase được hoạt hóa bởi adenosin monophosphat (AMPK), tín hiệu calmodulin và $\mathrm{AKT} / \mathrm{NOTCH}$. AMPK là một enzym điều hòa chuyển hóa được hoạt hóa bởi quá trình phosphoryl hóa thông qua con đường calcium/calmodulin protein kinase beta $(\mathrm{CaMKK} \beta)$ hoặc serine/threonine kinase11. Hoạt hóa AMPK ở gan được đặc trưng bởi các tác dụng chống tang glucose máu bao gồm giảm tân tạo glucose và quá trình tạo mỡ và thúc đẩy quá trình phân giải glucose và oxy hóa lipid. Hơn nữa, hoạt hóa AMPK ở gan ức chế hoạt động của Foxol dẫn đến giảm stress mạng lưới nội chất ở gan và giảm bớt kháng insulin và gan nhiễm mỡ. Leung và cộng sự đã phát hiện ra rằng liều cao 1,25 $(\mathrm{OH}) 2-\mathrm{D}$ có thể cải thiện bất thường chuyển hóa glucose và lipid ở gan trong các mô hình kháng insulin mà không có bất kỳ triệu chứng nhiễm độc nào. Điều này đã được xác nhận bởi Lin và cộng sự cho rằng mức tăng của 1,25- $(\mathrm{OH}) 2-\mathrm{D}$ dịch bào tương trongcáctế bào HepG2 dẫn đến việc hoạthóacác con đường $\mathrm{Ca}^{2+} / \mathrm{CaMKK} \beta / \mathrm{AMPK}$, từ đó xác nhận tác dụng điều hòa của calcitriol đối với glucose và lipid [18].

Người ta cũng chứng minh rằng tăng sự hình thành ROS là một chất hoạt hóa quan trọng của kháng insulin. Stress oxy hóa cùng tồn tại với bệnh đái tháo đường có thể là kêt quả của việc tăng nồng độ các acid béo tự do tác động lên ty thể để tăng sản xuất ROS (như hydro peroxide, superoxide, các ion gốc hydroxyl). Inoguchi và cộng sự đã chứng minh nồng độ glucose cao và các acid béo tự do có thể kích thích sản xuất ROS thông qua hoạt hóa phụ thuộc PKC của NADPH oxidase. Một số nghiên cứu đã chứng minh thiếu hụt vitamin $\mathrm{D}$ có liên quan đến sự suy giảm hô hấp ty thể xuất phát từ việc giảm các phân tử mRNA hạt nhân và các protein liên quan đến quá trình này. Hô hấp giảm gây suy giảm năng lượng sinh học ty thể tiếp theo biến đổi phosphoryl oxy hóa ty thể, giảm sự hình thành ATP và tăng sản xuất ROS. Đặc biệt, giảm biểu hiện phức hợp 1 của chuô̂i vận chuyển điện tử dẫn đến giảm sản xuất ATP và tăng sản xuất ROS. Mức độ tăng cao của ROS làm giảm hoạt động của các con đường tín hiệu insulin thông qua quá trình phosphoryl hóa serine/threonine của IRS, giảm phiên mã gen GLUT4, rối loạn phân phối lại tín hiệu insulin trong tế bào và thay đồi hoạt động của 
ty thể. Vai trò tiềm năng của vitamin $\mathrm{D}$ trong việc duy trì chức năng bình thường của ty thể có thể giải thích mối liên hệ giữa bệnh đái tháo đường và thiếu hụt vitamin $\mathrm{D}$ [24].

Vitamin $\mathrm{D}$ duy trì sự kiểm soát năng lượng sinh học tế bào trong ty thể và có thể điều hòa chức năng của ty thể. Cơ chế hoạt động của vitamin $\mathrm{D}$ thông qua thụ thể vitamin $\mathrm{D}$ trong nhân dẫn đến tăng biểu hiện của nhiều thành tố liên quan đến chức năng ty thể, bao gồm cả hô hấp ty thể. Tác dụng ức chế của tín hiệu 1,25-(OH)2-D/VDR đối với sự biệt hóa tế bào mõ̃ nâu và hô hấp ty thể cũng được quan sát thấy. VDR cũng đóng một vai trò quan trọng trong việc bảo vệ các tế bào không sản xuất quá mức ROS và hô hấp quá mức góp phần gây tổn thương tế bào. Vitamin $\mathrm{D}$ có liên quan đến cân bằng hô hấp của ty thể thông qua việc duy trì hoạt động của chuỗi hô hấp ty thể và điều hòa biểu hiện protein không kết cặp 1 (UCP1: Uncoupling protein 1). UCP1 được định vị trên màng trong ty thể và chịu trách nhiệm kiểm soát quá trình sinh nhiệt [26].

Vitamin $\mathrm{D}$ cũng có thể làm giảm sự hình thành ROS trong tế bào mỡ thông qua việc kiểm soát biểu hiện các chất chống oxy hóa tế bào. Vitamin $\mathrm{D}$ cùng với $\mathrm{Nrf2}$ (nuclear factor erythroid 2 $\square$ related factor 2) và Kloto (protein xuyên màng, kiểm soát về độ nhạy cảm của sinh vật với insulin và liên quan đến lão hóa) có thể điều hòa sự biểu hiện của nhiều chất chống oxy hóa. Vitamin D đã được ghi nhận điều hòa giảm NADPH oxydase $\left(\mathrm{NO}_{\mathrm{X}}\right)$ tạo ra ROS, trong khi điều hòa tăng superoxide dismutase (SOD) chịu trách nhiệm chuyển superoxide thành hydro peroxide. Hơn nữa, vitamin $\mathrm{D}$ làm tăng sản xuất glutathione (GSH), bộ đệm oxi hóa khử chính thông qua việc điều hòa tăng glutamate cysteine ligase, glucose-6-phosphate dehydrogenase (G6PD) và glutathione reductase [26].

2.2.3. Vitamin $D$ điều chỉnh các thay đổi biểu sinh gọi lên tiềm năng tăng điều hòa đối với các gen demethylase DNA

Ở người béo phì, sự methyl hóa DNA gia tăng và được xác định là một trong các yếu tố nguy cơ phát triển đái tháo đường. Scavenger Receptor Class A Member 3 (SCARA3) và
Peroxiredoxin-2 ( PRDX2 ) là các gen bị bất hoạtdo tăng methyl hóa, dẫn đến tăng ROS.Cácgen SCARA3 và PRDX2 mã hóa các protein làm giảm nồng độ ROS. Vitamin $\mathrm{D}$ giúp duy trì sự biểu hiện các gen demethylase DNA thông qua cơ chế hoạt động qua gen. Theo cách này, vitamin $\mathrm{D}$ điề̀u hòa sự biểu hiện demethylase DNA phụ thuộc vitamin $\mathrm{D}$, tức là demethylase đặc hiệu lysine 1 và 2 (LSD1 và $L S D 2)$ và protein chứa miền Jumonji $1 \mathrm{~A}$ và 3 (JMJD1A và JMJD3). Các enzym này ngăn chặn quá trình tăng methyl hóa của các vùng khởi xướng của nhiều gen [4].

\subsubsection{Vitamin D vù̀a là chất kích thích và úc chế quá trình tạo mõ}

Sự tạo mỡ là một quá trình của các giai đoạn biệt hóa liên tiếp dẫn đến hình thành các tế bào mỡ trưởng thành. Tế bào mỡ trưởng thành có thể thực hiện nhiều chức năng như tiết các adipokin, đáp ứng với tín hiệu insulin, lưu thông acid béo qua màng và tổng hợp lipid. Sự biệt hóa tiền tế bào mỡ thành các tế bào mỡ trưởng thành liên quan đến các phân tử tín hiệu nội bào, như các protein SMAD, ribosomal protein S6 kinase 1 (S6K1), và janus kinase-signal transducer và activator of transcription 3 (JAK-STST3), ảnh hưởng đến các yếu tố phiên mã tạo mỡ. Sự biệt hóa tế bào mỡ được điều hòa thông qua nhiều yếu tố phiên mã như protein liên kết điều hòa sterol 1 (SREBP1: Sterol regulatory binding protein 1), chất điều hòa chính của thụ thể được hoạt hóa bởi yếu tố biệt hóa ở peroxisome gamma $(\mathrm{PPAR} \gamma)$ và các protein liên kết chất tăng cường/điều hòa CAAT (Cytosine-cytosineadenosine-adenosine-thymidine/enhancer binding proteins) (C/EBP $\beta, \quad \mathrm{C} / \mathrm{EBP} \alpha$, $\mathrm{C} / \mathrm{EBP} \delta$ ). Vai trò của các yếu tố phiên mã này là sự cảm ứng biểu hiện của nhiều gen liên quan đến quá trình phân giải lipid, hình thành lipid và nhạy cảm insulin như chất vận chuyển glucose (GLUT4), lipoprotein lipase (LPL), synthase acid béo (FASN: Fatty acid synthase) và protein liên kết với acid béo (FABP4: Fatty acid binding protein) [26].

Vitamin $\mathrm{D}$ có tác động đến điều hòa quá trình tạo mỡ. VDR được biểu hiện ở các tế 
bào mỡ trong giai đoạn đầu của quá trình tạo mỡ và mức độ của nó giảm dần theo tiến trình biệt hóa. Ngược lại với tác dụng ức chế của vitamin $\mathrm{D}$ đối với quá trình tạo mỡ trong tiền tế bào mõ̃ 3T3-L1 ở chuột và ức chế biệt hóa tế bào mỡ nâu, vitamin $\mathrm{D}$ đã được phát hiện thúc đẩy quá trình tạo mỡ ở tiền tế bào mỡ người và chuột sơ cấp. Nồng độ $1,25-(\mathrm{OH}) 2$ $\mathrm{D}$ cao có thể ức chế giai đoạn đầu của quá trình tạo mỡ trong các tế bào 3T3-L1. Calcitriol ngăn chặn quá trình tạo mỡ thông qua tác động lên nhiều mục tiểu ức chế sự biểu hiện của $\mathrm{PPAR} \gamma$ và $\mathrm{C} / \mathrm{EBP} \alpha$, hoạt động đối kháng của PPAR $\gamma$ cô lập $R X R$ và giảm mRNA và biểu hiện protein hạt nhân của C/EBP $\beta$. 1,25- $(\mathrm{OH}) 2-\mathrm{D}$ liên quan đến biểu hiện của chất ức chế lõi $\mathrm{C} / \mathrm{EBP} \beta$-eight twentyone (ETO), chất ngăn chặn tác dụng của hoạt động phiên mã $\mathrm{C} / \mathrm{EBP} \beta$ cần thiết cho quá trình tạo mỡ. Nhiều phân tử tín hiệu, bao gồm các thành viên của gia đình WNT (một nhóm các con đường truyền tín hiệu bắt đầu với protein mà vượt qua tín hiệu vào một tế bào thông qua thụ thể bề mặt tế bào, Wnt tạo ra từ tên Wingless và tên Int-1) được tiết ra ở giai đoạn biệt hóa tiền tế bào mỡ. Thông thường, con đường $\mathrm{WNT} / \beta$-catenin được điều hòa giảm trong quá trình tạo mỡ và duy trì các tiền tế bào mỡ ở tình trạng không biệt hóa. Vitamin D góp phần ức chế sự biệt hóa tế bào mỡ thông qua các con đường tín hiệu Wnt/ $\beta$-catenin và MAPK. Người ta đã chứng minh rằng $1,25-(\mathrm{OH}) 2-\mathrm{D}$ duy trì biểu hiện $\beta$-catenin nhân và $\mathrm{WNT} 10 \mathrm{~B}$, do đó ức chế PPAR $\gamma$ và cho thấy tác dụng chống tạo mỡ trong tiền tế bào mỡ 3T3-L1. Calcitriol cũng được báo cáo là làm giảm mức độ biểu hiện của secreted fizzled-related protein 2 (SFRP2) thông qua tín hiệu WNT qua trung gian VDR dẫn đến ức chế sự biệt hóa của các tế bào mô tủy xương chuột (BMSCs: Bone marrow mononuclear cells). Hơn nữa, 1,25$(\mathrm{OH}) 2-\mathrm{D}$ ức chế cả biểu hiện mRNA và sự phosphoryl hóa kinase được điều hòa ngoại bào (ERK: Extracellular regulated kinase), do đó kích hoạt sự ức chế biệt hóa tế bào mỡ. Ngoài ra, calcitriol làm tăng biểu hiện của các dấu ấn tạo mõ̃ LPL và FABP4 thúc đẩy sự biệt hóa của tiền tế bào mỡ dưới da ở người[26].

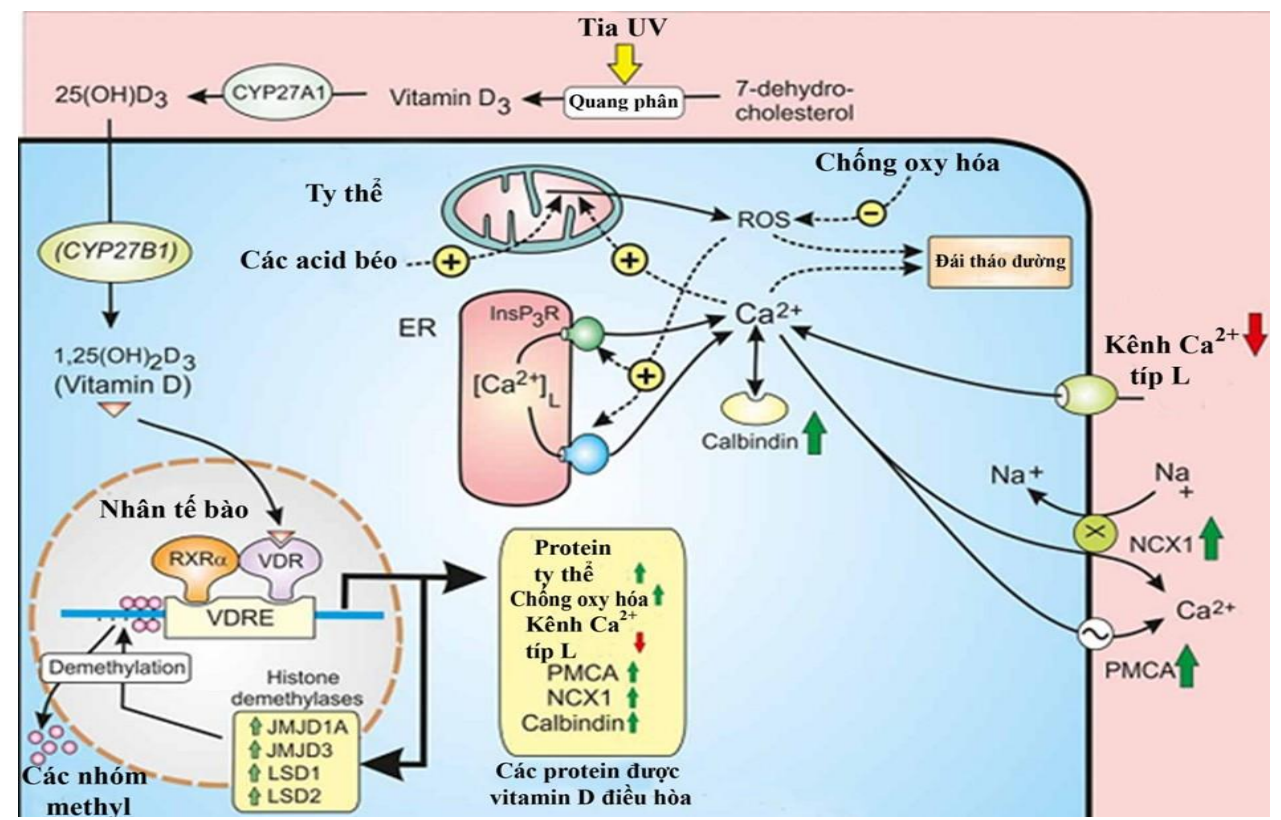

Hình 6. Vitamin D có tác dụng ngăn ngùa đái tháo đương bằng cách duy trì nồng độ thấp của $\mathrm{Ca}^{2+}$ và ROS [4]. 
Sự tiếp xúc của các tế bào gốc trung mô của lợn (MSCs: Porcine mesenchymal stem cells) với vitamin $\mathrm{D}$ gây ra cả sự tăng sinh và biệt hóa bằng cách tăng biểu hiện mRNA của protein liên kết với tế bào mỡ 2 (AP2: adipocyte-binding protein 2), lipoprotein lipase (LPL) và PPAR $\gamma$. Nó cũng chỉ ra rằng các tế bào trung mô trải qua quá trình biệt hóa đối với các tế bào mỡ với biểu hiện tăng đi cùng của $\mathrm{FABP} 4, \mathrm{FASN}$ và $\mathrm{PPAR} \gamma$ cũng như tăng cường tích lũy lipid do kết quả của tiếp xúc với 1,25-(OH)2-D [23].

\subsubsection{Vai trò của vitamin D đối với chết tế bào mõ theo chương trình}

Calcitriol ức chế chết tế bào theo chương trình và kích thích sự biểu hiện của các gen gây tăng sinh trong tế bào mỡ dưới da người. Liều cao calcitriol gây kích thích, trong khi đó liều thấp đã ức chế chết tế bào theo chương trình trong các tế bào 3T3-L1 được biệt hóa. Vitamin $\mathrm{D}$ liều thấp có tác dụng ức chế chết tế bào theo chương trình thông qua việc tăng tiềm năng ty thể và hiệu suất ATP cũng như ức chế UCP2. Dạng hoạt tính sinh học của vitamin $\mathrm{D}$ kích thích cả dòng $\mathrm{Ca}^{2+}$ phụ thuộc điện thế và không nhạy cảm điện thế trong các tế bào mỡ trưởng thành. Nó dẫn đến việc giải phóng $\mathrm{Ca}^{2+}$ từ lưới nội chất thông qua các thụ thể ryanodine (RyR: The ryanodine receptor) và thụ thể inositol trisphosphate (InsP $\mathrm{P}_{3} \mathrm{R}$ : Inositol trisphosphate receptor). Tăng nồng độ $\mathrm{Ca}^{2+}$ nội bào hoạt hóa chết tế bào theo chương trình thôngqua calpainprotease phụ thuộc $\mathrm{Ca}^{2+}$ dẫn đến hoạt hóa caspase-12phụ thuộc $\mathrm{Ca}^{2+} /$ calpain[26].

\subsubsection{Vitamin D làm giảm viêm chuyển hóa cùng tồn tại với kháng insulin}

Nơi lưu trữ chính của vitamin $\mathrm{D}$ trong cơ thể là mô mỡ. Mô mỡ biểu hiện cả VDR và các enzym tham gia chuyển hóa vitamin

$\mathrm{D}$. Bằng chứng gần đây chỉ ra rằng vitamin $\mathrm{D}$ tương tác với các phân tử làm vai trò cầu nối liên quan viêm, thụ thể màng, protein điều hòa lõi nhân và phosphatase trong mô mỡ. Do đó, vitamin $\mathrm{D}$ có liên quan đến tín hiệu tế bào và kiểm soát biểu hiện gen[1].

Béo phì được đặc trưng bởi sự phì đại của mô mỡ dẫn đến lưu lượng máu không phù hợp, từ đó dẫn đến sự xâm nhập của đại thực bào, thiếu oxy và viêm. Một đặc tính đặc biệt của các tế bào mỡ bị phì đại là tăng giải phóng các cytokin gây viêm như IL-8, IL6, TNF- $\alpha$, MCP1 và resistin, cũng như giảm tiết adiponectin. Do đó, một trong các hậu quả của béo phì là sự thay đổi tiết adipokin. Sự rối loạn điều hòa của nhiều con đường trong mô mỡ phì đại dẫn đến sự khởi phát kháng insulin. Vitamin D làm giảm viêm liên quan đến kháng insulin, hiệu ứng này được kết nối với điều biến tiết adipokin, chẳng hạn như adiponectin và leptin, bởi vitamin $\mathrm{D}$ [26].

Adiponectin là một loại hormon chống viêm và nhạy cảm với insulin, là một dấu ấn sinh học của kháng insulin. Hoạt tính sinh học của nó phụ thuộc vào nồng độ của nó trong huyết thanh, các đồng phân và phân nhóm thụ thể đặc hiệu cho mô. Mối tương quan nghịch giữa adiponectin lưu hành và chỉ số khối cơ thể (BMI) đã được chứng minh. Sự điều hòa giảm của adiponectin, đặc biệt là đồng phân trọng lượng phân tử cao (HMW: High molecular weight) đã được quan sát thấy ở trẻ béo phì bị thiếu hụt vitamin D. Có sự gia tăng đáng kể nồng độ adiponectin đã được tìm thấy ở người mắc đái tháo đường típ 2 được bổ sung thực phẩm tăng cường vitamin $\mathrm{D}$. Điều trị vitamin $\mathrm{D}$ làm tăng biểu hiện của adiponectin và disulfide bond-A oxidoreductase-like protein (DsbA-L). DsbAL là một protein điều hòa đa lượng đối với adiponectin [29].

Leptin được giải phóng bởi mô mỡ tác động lên vùng dưới đồi dẫn đến giảm cảm giác thèm ăn. Hormon này điều hòa quá trình chuyển hóa lipid thông qua việc kích thích phân giải lipid và ức chế quá trình tạo lipid. Nồng độ leptin tăng lên kích thích não ức chế sự thèm ăn và tăng tiêu hao năng lượng. Sự tổng hợp leptin được kích thích bởi glucocorticosteroid, insulin, estrogen và TNF$\alpha$, trong khi nó bị ức chế bởi hormon tăng trưởng và các acid béo tự do. Mối tương quan tích cực giữa nồng độ leptin và khối lượng mỡ cơ thể đã được quan sát thấy [17].

Vitamin $\mathrm{D}$ đóng một vai trò quan trọng, 
không chỉ trong việc điều hòa tiết các adipokin, mà còn trong việc kiểm soát cân bằng nội môi năng lượng thông qua điều hòa sự hình thành leptin. Vitamin $\mathrm{D}$ ức chế tiết leptin bởi mô mõ̃. Chuột loại bỏ CYP27B1 bị hạ leptin máu và tiêu thụ nhiều thực phẩm hơn so với chuột hoang dã. Chuột bị loại bỏ VDR (VDRKO: VDR knockout) đặc trưng bởi hạ leptin máu, kiểu hình nạc và có chứng ăn vô độ liên quan đến nồng độ leptin huyết thanh thấp. Leptin ức chế hoạt hóa vitamin $\mathrm{D}$ thành 1,25-(OH)2-D ở thận gián tiếp thông qua việc kích thích sản xuất FGF-23 ở tế bào xương hoặc nguyên bào xương, hoặc cả hai. FGF-23 ngăn chặn sự tổng hợp 1,25-(OH)2-D thông qua ức chế CYP27B1 ở thận. Suy giảm sự phát triển mô mõ̃ trắng và tiết leptin xảy ra ở chuột Vdr-/- và CYP27B1-/- [5].

Dạng hoạt tính sinh học của vitamin D được biết đển từ chức năng điều hòa miễn dịch. Kết quả của một số nghiên cứu trong ống nghiệm đã chỉ ra rằng calcitriol ngăn chặn tình trạng viêm mạn tính ở tế bào mỡ người và dòng tế bào 3T3-LI chuột. Bằng chứng mới nhất đã chứng minh rằng sự giảm tiết qua trung gian vitamin $\mathrm{D}$ của các cytokin tiền viêm là nguyên nhân làm giảm viêm mô mỡ. Mô mỡ trắng tích lũy các đại thực bào giải phóng các cytokin tiền viêm, bao gồm TNF- $\alpha$ có vai trò quan trọng trong sự phát triển của kháng insulin. Calcitriol ức chế tiết protein hóa hướng động bạch cầu đơn nhân -

1 (MCP-1: Monocyte chemoattractant protein-1) gây ra bởi TNF- $\alpha$, nhưng ức chế tiết adiponectin trong các tế bào mỡ biệt hóa từ mô mỡ trắng dưới da. Hơn nữa, 1,25$(\mathrm{OH}) 2-\mathrm{D}$ làm giảm biểu hiện gây ra bởi IL$1 \beta$ của các gen tiền viêm như IL-6, IL8 và $\mathrm{MCP}-1$ [26].

$\mathrm{NF}-\kappa \mathrm{B}$ là thành tố thiết yếu của quá trình viêm trong mô mõ̃. Việc hoạt hóa $N F-\kappa B$ và chuyển vị của tiểu đơn vị p65 vào nhân có liên quan đến sự thoái biến I $\mathrm{I} \mathrm{B} \alpha$. Calcitriol ức chế giải phóng IL-6 được kích thích bằng LPS trong các tế bào mỡ người trưởng thành và tế bào gốc trung mô được biệt hóa. Một tác dụng ức chế của vitamin $\mathrm{D}$ đối với các dấu hiệu viêm trong tế bào mỡ của người và chuột thông qua con đường viêm $\mathrm{NF}-\kappa \mathrm{B}$ và p38 MAP kinase cũng đã được chứng minh. Các thụ thể được kích thích bằng lipopolysaccharid (LPS) hoặc TNF- $\alpha$ như TLR, IL-6R hoạt hóa phiên mã phụ thuộc p38MAPK hoặc NF-kB của các gen gây viêm bao gồm IL-1 $\beta$, IL-6, TNF- $\alpha$. 1,25$(\mathrm{OH}) 2-\mathrm{D}$ ngăn chặn tình trạng viêm thông qua sự ức chế quá trình phosphoryl hóa $\mathrm{I} \kappa \mathrm{B} \alpha$

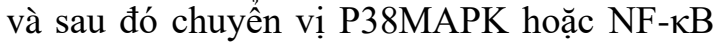
vào nhân [1].

Các cytokin cũng có thể kích thích cả con đường $\mathrm{IKK}-\beta / \mathrm{NF}-\kappa \mathrm{B}$ và Jun $\mathrm{N}$-terminal kinase 1 (JNK1). Đổi lại, các kinase được kích hoạt này có thể phosphoryl hóa IRS-1, dẫn đến giảm tín hiệu insulin. Do đó, việc tiết quá mức các cytokin gây viêm dẫn đến rối loạn chuyển hóa lipid và glucose. Bằng chứng ngày càng tăng cho thấy vitamin $\mathrm{D}$ làm giảm hóa hướng động bạch cầu đơn nhân và tiết cytokin và chemokin đóng vai trò chính trong viêm [1].

Vitamin D không chỉ có tác dụng chống viêm mà còn điều chỉnh chức năng hệ thống miễn dịch. Vitamin $\mathrm{D}$ làm giảm viêm mô mỡ tác động lên sự xâm nhập bạch cầu và sự trưởng thành của tế bào mỡ. Vitamin $\mathrm{D}$ có thể ảnh hưởng đến hoạt động của hệ thống miễn dịch bẩm sinh và thích nghi. Tác dụng của nó đối với các tế bào đuôi gai bao gồm tăng sản xuất IL-10 kháng viêm và giảm giải phóng các cytokin gây viêm như TNF- $\alpha$, IL-12 và interferon-gamma (IFN- $\gamma)$. Hơn nữa, các tế bào đuôi gai có được các đặc tính dung nạp và vai trò điều hòa miễn dịch do tiếp xúc với vitamin D. Trong bạch cầu đơn nhân, vitamin $\mathrm{D}$ làm giảm sự biểu hiện và sản xuất các cytokin tiền viêm như IL-1 $\beta, \mathrm{TNF}-\alpha$, IL6 và $\mathrm{IL}-8$. Trong các tế bào lympho, vitamin $\mathrm{D}$ tham gia chuyển từ đáp ứng viêm nhiều hơn của T-helper 1 (Th1)/Th17 sang Th2/Treg ít viêm hơn. Vì mô mỡ chứa một lượng lớn tế bào miễn dịch, nó đóng vai trò chính trong việc duy trì cân bằng nội môi miễn dịch. Hoạt động của tế bào lympho $\mathrm{T}$ được điều biến trong béo phì. Các tế bào $\mathrm{T}$ điều hòa (Treg) là phân nhóm của tế bào lympho $\mathrm{T}$ giảm đáng kể trong mô mỡ nội tạng của chuột béo phì. Gần 
đây, hai cơ chế quan trọng liên quan đến kháng insulin đã được làm rõ, phụ thuộc và không phụ thuộc vào béo phì. Kháng insulin liên quan đến béo phì được cho là do viêm bởi đại thực bào. Không phụ thuộc béo phì, tình trạng kháng insulin liên quan đến tuổi, được điều hòa thông qua các tế bào $\mathrm{T}$ điều tiết cư trú ở mô mỡ (aTregs). Vitamin $\mathrm{D}$ làm giảm viêm do khả năng tăng cường hoạt động ức chế của Tregs [31].

Vitamin $D$ là một chất điều chỉnh nghịch tiềm năng của việc giải phóng các cytokin gây viêm, làm giảm IL- $6, T N F-\alpha$ và protein phản ứng $\mathrm{C}$, và nó có tác dụng đáng kể đối với hệ thống miễn dịch và mô mỡ. Calcitriol cũng ngăn chặn mạnh mẽ việc hoạt hóa các con đường tín hiệu $\mathrm{MAPK}$ và $\mathrm{NF}-\kappa \mathrm{B}$, ngăn chặn sự phiên mã các gen của các yếu tố gây viêm. Do đó, dạng hoạt tính sinh học của vitamin $\mathrm{D}$ làm giảm đáng kể tình trạng viêm trong mô mỡ [26].

3. Các nghiên cứu về vitamin $D$ với kháng insulin và hội chứng chuyển hóa

3.1. Các nghiên cứu quan sát về mối liên quan giữa nồng độ vitamin $D$ và các thông số chuyển hóa liên quan đến kháng insulin

Nghiên cứu của $L u$ và cộng sự [20] về nồng độ 25-hydroxyvitamin $\mathrm{D}$ huyết tương và hội chứng chuyển hóa ở người trung niên và cao tuổi Trung Quốc (1443 nam giới và 1819 nữ giới độ tuổi 50-70). Thiếu hụt vitamin $\mathrm{D}$ phổ biến ở người trung niên và cao tuổi Trung Quốc, và nồng độ 25-OH-D thấp có liên quan đáng kể đến việc tăng nguy cơ mắc hội chứng chuyển hóa và kháng insulin.

Gagnon và cộng sự [13] đánh giá mối liên quan trong tương lai giữa $25-\mathrm{OH}-\mathrm{D}$ và hội chứng chuyển hóa và quan sát thấy nguy cơ tăng $141 \%$ và $174 \%$ ở đối tượng có $25-\mathrm{OH}-$ $\mathrm{D}<18 \mathrm{ng} / \mathrm{mL}$ và 18 đến $23 \mathrm{ng} / \mathrm{mL} ; 25-\mathrm{OH}-\mathrm{D}$ huyết thanh có liên quan nghịch với chu vi vòng bụng, triglycerid, glucose lúc đói và HOMA-IR. Thiếu hụt và không đủ vitamin $\mathrm{D}$ có liên quan đến sự gia tăng nguy cơ hội chứng chuyển hóa, chu vi vòng bụng, triglycerid, glucose lúc đói, và kháng insulin cao hơn sau 5 năm. Deleskog và cộng sự [10] đã cung cấp bằng chứng thuyết phục rằng thiếu hụt vitamin $\mathrm{D}$ thúc đẩy nhanh tiến triển từ tiền đái đường đến đái tháo đường típ 2 ở 980 nữ giới và 1398 nam giới, độ tuồi 35 - 56 không biết mắc đái tháo đường típ 2, theo dõi 8-10 năm. Điều đáng chú ý là giảm tỷ lệ mắc $21 \%$ (nữ) và $27 \%$ (nam) cho mỗi lần tăng nồng độ $25-\mathrm{OH}-\mathrm{D}$ là $10 \mathrm{nmol} / \mathrm{L}(4 \mathrm{ng} / \mathrm{mL})$.

Tepper và cộng sự [27] đã nghiên cứu ở 358 nam giới trưởng thành nhằm xác định ngưỡng cho sự thiếu hụt vitamin $\mathrm{D}$ liên quan đến các dấu hiệu chuyển hóa tim. Tình trạng thiếu hụt $(25-\mathrm{OH}-\mathrm{D}<12 \mathrm{ng} / \mathrm{ml})$ là $10,6 \%$; $29,9 \%$ là không đủ $(12<25-\mathrm{OH}-\mathrm{D}<20 \mathrm{ng} / \mathrm{ml})$ và $59,5 \%$ có đủ $(25-\mathrm{OH}-\mathrm{D}>20 \mathrm{ng} / \mathrm{ml})$. BMI, chu vi vòng bụng, insulin đói, HOMA-IR, TG, hs-CRP, HA tâm trương và tâm thu có mối liên quan nghịch với 25-OH-D huyết thanh. Đề xuất ngưỡng 25-OH-D là 11-14 $\mathrm{ng} / \mathrm{ml}$ có liên quan đến các chỉ số chuyển hóa tim ở nam giới khỏe mạnh.

Nghiên cứu của Junling Fu và cộng sự [12] 559 đối tượng 14-28 tuổi người Trung Quốc có nguy cơ mắc hội chứng chuyển hóa cao. Nồng độ 25-OH-D thấp hơn đáng kể ở các đối tượng tham gia có béo phì, triglycerid cao, đái tháo đường típ 2 hoặc hội chứng chuyển hóa. Các đối tượng có nồng độ $25-$ OH-D thấp nhất có khả năng mắc hội chứng chuyển hóa cao hơn 2,5 lần.

Al-Dabhani và cộng sự [2] đã nghiên cứu tỷ lệ thiếu hụt vitamin $\mathrm{D}$ và mối liên quan với hội chứng chuyển hóa trong dân số Qatar với 1205 người tham gia. Vitamin $\mathrm{D}$ huyết thanh thấp hơn $8 \%$ ở các đối tượng mắc hội chứng chuyển hóa so với các đối tượng không mắc hội chứng chuyển hóa.

Nghiên cứu kiểm soát trường cắt ngang của Rodrigo carnero và cộng sự [7] ở 299 đối tượng trên 18 tuổi. Thiếu hụt 25-OH-D xảy ra nhiều hơn ở những người có chu vi vòng bụng lớn hơn $102 \mathrm{~cm}$ (nam) và $88 \mathrm{~cm}$ (nữ), có triglycerid lớn hơn $150 \mathrm{mg} / \mathrm{dL}$ và có glucose máu lúc đói lớn hơn $100 \mathrm{mg} / \mathrm{dL}$. Tình trạng vtamin $\mathrm{D}$ thấp có mối tương quan nghịch có ý nghĩa với hội chứng chuyển hóa và các biến số khác. Một mối liên quan nghịch cũng được phát hiện với nguy cơ phát triển đái tháo đường típ 2. 
3.2. Các thử nghiệm lâm sàng can thiệp tập trung vào hiệu quả của việc bổ sung vitamin $D$ đối với các thông số chuyển hóa liên quan đến kháng insulin

Một thử nghiệm ngẫu nhiên có kiểm soát của El Hajj và cộng sự[11] nhằm đánh giá hiệu quả của điều trị vitamin $\mathrm{D}$ đối với cân bằng nội môi và chuyển hóa glucose ở 115 người cao tuổi Lebanon trong 6 tháng, nhóm can thiệp sử dụng 30000 IU cholecalciferol mỗi tuần. Bổ sung vitamin $\mathrm{D}$ làm giảm đáng kể HOMA-IR, cholesterol toàn phần và LDLcholesterol và nồng độ glucose máu đói trong nhóm can thiệp so với giả dược.

Mitri và cộng sự [22] đã nghiên cứu tác dụng của việc bổ sung vitamin $D$ và calci đối với chức năng tế bào $\beta$ tụy, nhạy insulin và glucose máu ở 92 người trưởng thành có nguy cơ mắc đái tháo đường típ 2 trong 16 tuần. Kết quả cho thấy bổ sung ngắn hạn với cholecalciferol đã cải thiện chức năng tế bào $\beta$ và có hiệu ứng tức thời trong việc làm giảm sự gia tăng $\mathrm{HbA1c}$.

Nghiên cứu của Lê Quang Toàn ở 104 thai phụ mắc đái tháo đường thai kỳ(ĐTĐTK) cho thấy nồng độ $25-\mathrm{OH}-\mathrm{D}$ huyết tương có tương quan tuyến tính nghịch với kháng insulin ở thai phụ mắc ĐTĐTK vào tuần thai $24-28$; Tỷ lệ thiếu 25-OH-D (< $75 \mathrm{nmol} / \mathrm{L})$ có liên quan với tăng kháng insulin ở thai phụ mắc ĐTĐTK vào tuần thai $24-28$. Sau bổ sung vitamin $\mathrm{D}$ từ tuần thai $24-28$ đến tuần thai 36 - 38, nhóm $1500 \mathrm{IU} /$ ngày có giảm sự gia tăng kháng insulin $71,2 \%$ theo HOMA2 tính bằng insulin và $77,4 \%$ theo HOMA2 tính bằng $\mathrm{C}$-peptid so với nhóm bổ sung 500 IU/ngày [19].

Thử nghiệm lâm sàng của Upreti và cộng sự [28] về hiệu quả của việc bổ sung vitamin $\mathrm{D}$ bằng đường uống đối với việc kiểm soát glucose máu ở 60 người mắc đái tháo đường típ 2 có thiếu vitamin D trong 6 tháng, uống $60000 \mathrm{IU}$ vitamin $\mathrm{D}$ mỗi tuần trong 6 tuần đầu tiên, sau đó 4 tuần 1 lần cho đến khi kết thúc điều trị; nhóm giả dược uống cellulose tinh thể. Bổ sung vitamin $\mathrm{D}$ bằng đường uống có liên quan đến việc cải thiện kiểm soát glucose máu và các thông số chuyển hóa khác ở người bệnh đái tháo đường týp 2.

Một phân tích tổng hợp các nghiên cứu can thiệp của $\mathrm{Hu}$ và cộng sự [16] về hiệu quả của việc bổ sung vitamin $\mathrm{D}$ trong kiểm soát glucose máu ở người bệnh đái tháo đường típ 2. Tổng cộng 19 nghiên cứu thử nghiệm ngẫu nhiên có đối chứng liên quan đến 747 đối tượng can thiệp và 627 đối chứng giả dược. Kết quả phân tích tổng hợp cho thấy so với nhóm chứng, nhóm bồ sung vitamin $\mathrm{D}$ ngắn hạn giúp giảm $\mathrm{HbA} 1 \mathrm{c}$, kháng insulin và insulin.

\section{KẾT LUẬN}

Các phát hiện gần đây cho thấy nền tảng phân tử của sự hình thành kháng insulin có liên quan đến thiếu hụt vitamin D. Cả hoạt động phân tử qua gen và không qua gen của vitamin $\mathrm{D}$ đều liên quan đến duy trì sự nhạy cảm insulin. Các tác dụng thuận lợi này không chỉ liên quan trực tiếp đến tín hiệu insulin, mà còn gián tiếp thông qua giảm stress oxy hóa, viêm chuyển hóa và điều hòa biểu sinh của biểu hiện gen cũng như hệ thống renin-angiotensin-aldosterone. Kết quả của các nghiên cứu cơ bản và lâm sàng cho thấy thiếu hụt vitamin $\mathrm{D}$ là một yếu tố quan trọng có thể đẩy nhanh quá trình hình thành kháng insulin trong hội chứng chuyển hóa. Hiểu sâu hơn về sự tham gia của phân tử vitamin $\mathrm{D}$ trong các quá trình liên quan đến tín hiệu insulin có thể dẫn đến các chiến lược điều trị mới ngăn ngừa sự phát triển của các rối loạn chuyển hóa liên quan đến kháng insulin.

\section{TÀI LIỆU THAM KHẢO}

1. Abbas M. A. (2017), "Physiological functions of Vitamin D in adipose tissue", The Journal of Steroid Biochemistry and Molecular Biology. 165, pp. 369-381.

2. Al-Dabhani K. et al. (2017), "Prevalence of vitamin $\mathrm{D}$ deficiency and association with metabolic syndrome in a Qatari population", Nutrition \& diabetes. 7 (4), pp. e263.

3. Angela C. et al. (2018), "Determining Factors of Arterial Stiffness in Subjects 
with Metabolic Syndrome", Metabolic syndrome and related disorders. 16 (9), pp. 490-496.

4. Berridge M. J. (2017), "Vitamin D deficiency and diabetes", Biochemical Journal. 474 (8), pp. 1321-1332.

5. Bouillon R. et al. (2014), "Vitamin D and energy homeostasis - of mice and men", Nature Reviews Endocrinology. 10 (2), pp. 79.

6. Bresson J. et al. (2016), "Scientific opinion on dietary reference values for vitamin D EFSA panel on dietetic products, nutrition, and allergies (NDA)", EFSA J. 179, pp. 86-87.

7. Carnero R. et al. (2019), "SUN-138 Association Between The Deficit Of 25 (oh) Vitamin D, Metabolic Syndrome And New Onset Of Type 2 Diabetes", Journal of the Endocrine Society. 3 (Supplement_1), pp. SUN-138.

8. Combs Gerald F, McClung James P (2017), The Vitamins: Fundamental Aspects in Nutrition and Health, Fifth Edition, Elsevier Inc, 7, pp. 161-206.

9. Del Valle H. B. et al. (2011), Dietary reference intakes for calcium and vitamin $D$, National Academies Press.

10. Deleskog A. et al. (2012), "Low serum 25-hydroxyvitamin D level predicts progression to type 2 diabetes in individuals with prediabetes but not with normal glucose tolerance", Diabetologia. 55 (6), pp. 1668-1678.

11. El Hajj C. et al. (2018), "Effect of vitamin D treatment on glucose homeostasis and metabolism in lebanese older adults: A randomized controlled trial", The journal of nutrition, health \& aging. 22 (9), pp. 1128-1132.

12. Fu J. et al. (2018), "Vitamin D levels are associated with metabolic syndrome in adolescents and young adults: The BCAMS study", Clinical Nutrition.

13. Gagnon C. et al. (2012), "Low serum 25hydroxyvitamin $\mathrm{D}$ is associated with increased risk of the development of the metabolic syndrome at five years: results from a national, population-based prospective study (The Australian Diabetes, Obesity and Lifestyle Study: AusDiab)", The Journal of Clinical Endocrinology \& Metabolism. 97 (6), pp. 1953-1961.

14. Gil A. et al. (2018), "Vitamin D: Classic and Novel Actions", Annals of Nutrition and Metabolism. 72(2),pp.87-95.

15. Holick M. F. et al. (2011),"Evaluation, treatment, and prevention of vitamin D deficiency: an Endocrine Society clinical practice guideline", The Journal of Clinical Endocrinology \& Metabolism. 96 (7), pp. 1911-1930.

16. Hu Z. et al. (2019), "Efficacy of vitamin D supplementation on glycemic control in type 2 diabetes patients: A meta-analysis of interventional studies", Medicine. 98 (14)

17. Koszowska A. U. et al. (2014), "Obesity, adipose tissue function and the role of vitamin D", Central-European journal of immunology. 39 (2), pp. 260.

18. Leung P. (2016), "The potential protective action of vitamin $D$ in hepatic insulin resistance and pancreatic islet dysfunction in type 2 diabetes mellitus", Nutrients. 8 (3), pp. 147.

19. Lê Quang Toàn (2016). Nghiên cứu mối liên quan giũa nồng độ 25hydroxyvitamin D huyết twơng với kháng insulin và hiệu quả bổ sung vitamin $D$ đối với kháng insulin trong đái tháo đường thai kỳ, Luận án Tiến sỹ Y học, Trường Đại học Y Hà Nội.

20. Lu L. et al. (2009), "Plasma 25hydroxyvitamin $\mathrm{D}$ concentration and metabolic syndrome among middle-aged and elderly Chinese individuals", Diabetes care. 32 (7), pp. 1278-1283.

21. Manna P. et al. (2018), "1, $25(\mathrm{OH}) 2-$ vitamin D 3 upregulates glucose uptake mediated by SIRT1/IRS1/GLUT4 signaling cascade in $\mathrm{C} 2 \mathrm{C} 12$ myotubes", Molecular and cellular biochemistry. 444 (1-2), pp. 103-108.

22. Mitri J. et al. (2011), "Effects of vitamin D and calcium supplementation on 
pancreatic $\beta$ cell function, insulin sensitivity, and glycemia in adults at high risk of diabetes: the Calcium and Vitamin $D$ for Diabetes Mellitus (CaDDM) randomized controlled trial", The American journal of clinical nutrition. 94 (2), pp. 486-494.

23. Narvaez C. et al. (2013), "Induction of STEAP 4 correlates with 1, 25ロdihydroxyvitamin D3 stimulation of adipogenesis in mesenchymal progenitor cells derived from human adipose tissue", Journal of cellular physiology. 228 (10), pp. 2024-2036.

24. Scaini G. et al. (2016), "Mitochondrial dysfunction in bipolar disorder: evidence, pathophysiology and translational implications", Neuroscience \& Biobehavioral Reviews. 68, pp. 694-713.

25. Scientific Advisory Committee on Nutrition (SACN) and Health. 2016. Vitamin D]

26. Szymczak-Pajor I. et al. (2019), "Analysis of Association between Vitamin D Deficiency and Insulin Resistance", Nutrients. 11 (4), pp. 794.

27. Tepper S. et al. (2014), "Identifying the threshold for vitamin D insufficiency in relation to cardiometabolic markers", Nutrition, Metabolism and Cardiovascular Diseases. 24 (5), pp. 489494.

28. Upreti V. et al. (2018), "Effect of oral vitamin D supplementation on glycemic control in patients with type 2 diabetes mellitus with coexisting hypovitaminosis D: A parellel group placebo controlled randomized controlled pilot study", Diabetes \& Metabolic Syndrome: Clinical Research \& Reviews. 12 (4), pp. 509-512.

29. Walker G. E. et al. (2014), "Pediatric obesity and vitamin D deficiency: a proteomic approach identifies multimeric adiponectin as a key link between these conditions", PloS one. 9 (1), pp. e83685.

30. Wolden-Kirk H. et al. (2013), "Unraveling the effects of $1,25(\mathrm{OH})$ 2D3 on global gene expression in pancreatic islets", The Journal of Steroid Biochemistry and Molecular Biology. 136, pp. 68-79.

31. Zeng H. et al. (2015), "Metabolic control of regulatory $\mathrm{T}$ cell development and function", Trends in immunology. 36 (1), pp. 3-12. 